\title{
Transatlantic Air Travel in the Third Trimester of Pregnancy: Does It Affect the Fetus?
}

\author{
B. Petrikovsky, MD, $\mathrm{PhD}^{1} \quad$ M. Terrani, MD $\quad$ L. Sichinava, MD, $\mathrm{PhD}^{3}$ \\ ${ }^{1}$ Long Island OB/GYN, New Hyde Park, New York \\ 2 Sunny Isles Medical Center, Sunny Isles, Florida \\ ${ }^{3}$ Moscow University School of Medicine, Moscow, Russia.

\begin{abstract}
Address for correspondence B. Petrikovsky, MD, PhD, Long Island OB/GYN, 374 Stockholm Street, Brooklyn, NY 11237

(e-mail: bpetriko@gmail.com).
\end{abstract}

Am J Perinatol Rep 2018;8:e71-e73.

\begin{abstract}
Most commercial airlines allow pregnant women to fly up to 36 weeks of gestation. Available information suggests that noise, vibration, and cosmic radiation present a small risk for the pregnant air traveler. The goal of the study was to assess the possible effect of transatlantic flights on the condition of the third-trimester fetus. In total, 112 patients were recruited into the study between January 2005 and June 2016. All underwent a transatlantic flight in the third trimester of pregnancy. All underwent nonstress test before and within 12 hours after the transatlantic flight, and 24 hours later. Patients were asked to report changes in fetal movements (FMs), if any, during takeoff, flight itself, and landing. The time of flight varied from 8 to 15 hours; average

\section{Keywords}

- pregnancy

- travel

- fetus

- airplane flight time was $9 \pm 3.8$ hours. Ninety-eight patients were the passengers of first or business class, and the rest were of economy class. Increased FM during takeoff was reported by 17 patients (15\%), no change in FM by 62 (35\%), decreased FM by 4 (3.6\%). During flight itself, increased FM was reported by 6 pregnant passengers (5.4\%), no change in FM by 70 (63\%), decreased FM by $8(7 \%)$.
\end{abstract}

Most commercial airlines allow pregnant women to fly up to 36 weeks of gestation. ${ }^{1}$ Some restrict pregnant women from international flights earlier in gestation and some require documentation of gestational age. For specific airline requirements, women should check with the individual carrier. ${ }^{1}$ Recent cohort studies suggest no increase in adverse pregnancy outcomes for occasional air travelers for low-risk patients. ${ }^{2,3}$ Available information suggest that noise, vibration, and cosmic radiation present a small risk for the pregnant air traveler. ${ }^{4}$ Both the National Council on Radiation Protection and Measurements and the International Commission on Radiological Protection recommend a maximum annual radiation exposure limit of 1 millisievert $(\mathrm{mSv})(100 \mathrm{rem})$ for members of the general public and 1 mSv over the course of a 40 -week pregnancy. ${ }^{5}$ Even the longest available intercontinental flights will expose passengers to no more than $15 \%$ of this limit ${ }^{5}$; therefore, it is unlikely that the occasional traveler will exceed current exposure limits during pregnancy. However, aircrew or frequent flyers may exceed these limits. There is a paucity of information regarding risks of air travel in pregnancy, most of it stemming from fairly old series. ${ }^{3}$ While one study deduced that "such low level of hypoxia as that which in an aircraft has little effect on the fetus," another author argued that the "changing mechanics of pregnancy lend credence to the argument that pregnant stewardesses should not fly." 6,7

The goal of the study was to assess the possible effect of transatlantic flights on the condition of the third-trimester fetus.

\section{Materials and Methods}

One hundred and twelve patients were recruited into the study between January 2005 and June 2016. All underwent a transatlantic flight in the third trimester of pregnancy. All received

October 2, 2017

accepted after revision

February 23, 2018
DOI https://doi.org/

10.1055/s-0038-1641584. ISSN 2157-6998.
Copyright $\odot 2018$ by Thieme Medical Publishers, Inc., 333 Seventh Avenue, New York, NY 10001, USA. Tel: +1(212) 584-4662.
License terms

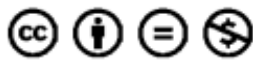


Table 1

\begin{tabular}{|l|l|l|l|}
\hline & $\begin{array}{l}\text { NST } \\
\text { before } \\
\text { flight }\end{array}$ & $\begin{array}{l}12 \mathrm{~h} \text { after } \\
\text { flight }\end{array}$ & $\begin{array}{l}\text { 24 h after } \\
\text { flight }\end{array}$ \\
\hline Reactive & $93 \%$ & $73 \%^{\mathrm{a}}$ & $94 \%$ \\
\hline $\begin{array}{l}\text { Presence of visible } \\
\text { decelerations }\end{array}$ & $6 \%$ & $14 \%$ & $4 \%$ \\
\hline
\end{tabular}

Abbreviation: NST, nonstress test.

patients were between 34 and 37 weeks of gestation. All underwent nonstress test (NST) before and within 12 hours after the transatlantic flight, and 24 hours later. Patients were asked to report changes in fetal movements (FMs), if any, during takeoff, flight itself, and landing.

Statistical evaluation was made using SPSS for Windows V 15.0 (SPSS Inc.). Data were shown as frequency (percentage) or mean \pm standard deviation.

\section{Results}

The time of flight varied from 8 to 15 hours; average flight time was $9 \pm 3.8$ hours. Ninety-eight patients were the passengers of first or business class, and the rest were of economy class. Patients' ages varied from 22 to 39 years, average being $26 \pm 5.2$ years. NST parameters are reflected in -Table 1.

Increased FM during takeoff was reported by 17 patients (15\%), no change in FM by 62 (35\%), decreased FM by 4 (3.6\%). During flight itself, increased FM was reported by 6 pregnant passengers (5.4\%), no change in FM by 70 (63\%), decreased FM by 8 (7\%).

\section{Discussion}

Magann et $\mathrm{al}^{8}$ conducted a literature review on air travel and pregnancy outcome among other issues (e.g., cosmic radiation, risk of acquiring respiratory disease, possibility of obstetrical emergencies) and addressed one of the possible risks to the fetus, aircraft noise.

A review of perinatal effects of noise emphasizes the lack of properly controlled studies to draw meaningful conclusions about the effects or lack of effects of noise on birth defects and perinatal outcomes. ${ }^{9}$ The World Health Organization has labeled noise of greater than $85 \mathrm{~dB}$ as potentially hazardous. ${ }^{10}$ In both military and civilian aircraft, the greatest noise exposure is during takeoff and landing. Indeed, Freeman et $\mathrm{al}^{3}$ observed increased fetal heart rate during takeoff and landing. The majority of our patients reported increased FMs at these times. It remains unclear whether these changes are caused by aircraft noise, maternal anxiety, or a combination of both. These fetal responses are very similar to the ones experienced by fetuses exposed to cell phone noise. Frequent acoustic stimulation by cell phones and beepers was accompanied by a startle response manifested by head turning toward the source of the sound, increased swallowing, and frequent eye blinking. Startle responses were observed in all fetuses of the study group and only in $12 \%$ of the fetuses in the control group. Besides causing startle response, acoustic stimulations were associated with changes in behavioral states, most notable, from quiet and active sleep into an awakened state. ${ }^{11,12}$

The partial pressure of oxygen in inspired air in airplane cabin environments maintained by cabin pressure is usually lower than that at sea level. Physiological adaptations to this relative reduction in inspired oxygen include an increase in heart rate, increase in blood pressure, and decrease in transcutaneously measured arterial oxygen saturation. Fetal hemoglobin has a greater affinity for oxygen than adult hemoglobin, and the fetus is able to maintain a higher oxygen saturation in this environment, which protects it during routine flight conditions. Most healthy pregnant women will have no adverse effects, but those with preexisting cardiovascular problems, sickle cell disease, or anemia ${ }^{13}$ may experience complications.

Our study demonstrated significant changes in FHR parameters immediately after the transatlantic flight. It manifested in the increased rate of nonreactive NSTs and more frequent appearances of variable decelerations. The strength of the paper is its prospective nature and the fact that all patients were flying the same or similar distances. In most previous studies, data from intercontinental and domestic flights were analyzed together, thus causing confusion. In spite of the fact that on long commercial flights, traveling at 39,000 to $41,000 \mathrm{ft}$., cabin pressure is maintained at the equivalent of an altitude pressure of 8,000 ft., whereas at $32,000 \mathrm{ft}$. (for shorter flights), cabin pressure is set at an equivalent of $6,000 \mathrm{ft}^{14}$ The conditions at a cabin pressure of $8,000 \mathrm{ft}$. will create a more hypoxic environment than those at 6,000 ft. At 6,000 ft., oxygen consumption in pregnant women is $13 \%$ ( $\mathrm{L} /$ minute) lower than that at sea level in comparison with nonpregnant women for whom the decrease is only $3 \%$ lower. $^{2}$ The limitations of the study are relatively small sample size and the subjective nature of FM assessment based on patients' diaries. Our study demonstrated that although transatlantic flights may cause only temporary changes in fetal behavior and appears safe for the fetus, these conclusions are limited to third-trimester fetuses.

\section{Conflict of Interest}

None.

\section{References}

1 ACOG Committee on Obstetric Practice. ACOG Committee Opinion Number 443: Air travel during pregnancy. Obstet Gynecol 2009;114(04):954-955

2 Chibber R, Al-Sibai MH, Qahtani N. Adverse outcome of pregnancy following air travel: a myth or a concern? Aust N Z J Obstet Gynaecol 2006;46(01):24-28

3 Freeman M, Ghidini A, Spong CY, Tchabo N, Bannon PZ, Pezzullo JC. Does air travel affect pregnancy outcome? Arch Gynecol Obstet 2004;269(04):274-277

4 Barish RJ. In-flight radiation exposure during pregnancy. Obstet Gynecol 2004;103(06):1326-1330 
5 Federal Aviation Administration. In-flight radiation exposure. Advisory Circular No. 120-61A. Washington, DC: FAA; 2006

6 Scholten P. Pregnant stewardess-should she fly? Aviat Space Environ Med 1976;47(01):77-81

7 Cameron RG. Should air hostesses continue flight duty during the first trimester of pregnancy? Aerosp Med 1973;44(05): 552-556

8 Magann EF, Chauhan SP, Dahlke JD, McKelvey SS, Watson EM, Morrison JC. Air travel and pregnancy outcomes: a review of pregnancy regulations and outcomes for passengers, flight attendants, and aviators. Obstet Gynecol Surv 2010;65(06):396-402

9 Morrell S, Taylor R, Lyle D. A review of health effects of aircraft noise. Aust N Z J Public Health 1997;21(02):221-236
10 Berglund B, Lindvall T, Schwela DH, et al. Guidelines for Community Noise. Geneva, Switzerland: WHO; 1999:1-141

11 Petrikovsky BM. Cell phones: be aware of the risks to the fetus. Neonatal Intensive Care 2016;30(01):29-35

12 Petrikovsky BM, Schifrin B, Diana L. The effect of fetal acoustic stimulation on fetal swallowing and amniotic fluid index. Obstet Gynecol 1993;81(04):548-550

13 Hezelgrave NL, Whitty CJM, Shennan AH, Chappell LC. Advising on travel during pregnancy. BMJ 2011;342:d2506

14 Brooks GA, Fahey TD, White TP, Baldwin KM. Exercise, atmospheric pressure, air pollution, and travel. In: Exercise Physiology: Human Bioenergetics and Its Applications. 3rd ed. Mountain View, CA: Mayfield Publishing Company; 2000:504-536 